ROCZNIKI NAUK SPOŁECZNYCH

Tom 12(48), numer 3 - 2020

DOI: https://doi.org/10.18290/rns20483-2

\title{
JÓZEF MŁYŃSKI
}

\section{RODZINA MIGRACYJNA BENEFICJENTEM SIECI WSPARCIA W POLSCE}

\section{WPROWADZENIE}

Termin „sieci wielorakiego wsparcia społecznego” jest wieloznaczny. Do jego kluczowych interpretacji należy social support. Przyjmuje się jednak, że pojęcie to ma status hipotetyczny. W literaturze przedmiotu nadal bowiem brakuje naukowych definicji, jak również istnieje niespójność, a może nawet incydentalność badań. Sposób rozumienia tego typu wsparcia zależy ponadto od wiedzy na temat funkcjonowania człowieka w grupach społecznych, od form relacji i interakcji w społeczności lokalnej oraz sytuacji uwarunkowanych różnymi problemami i trudnościami jednostki ${ }^{1}$. Z tej też racji wypada przywołać definicję Heleny Sęk, dla której wsparcie społeczne to „obiektywnie istniejące i dostępne sieci społeczne, które wyróżniają się od innych sieci tym, że poprzez fakt istnienia więzi, kontaktów społecznych, przynależności, pełnią funkcję pomocną wobec osób znajdujących się w trudnej sytuacji”’2.

W naukach społecznych i szeroko rozumianej literaturze przedmiotu zwykle wyróżnia się trzy kategorie wsparcia: personalne, formalne i profesjonalne.

Dr hab. JÓZEF MŁYŃSKI, prof. UP - Uniwersytet Pedagogiczny im. KEN w Krakowie; adres do korespondencji: ul. Lwowska 102, 33-100 Tarnów; e-mail: jozef.mlynski@up.krakow.pl; jmlynski@poczta.fm; ORCID: https://orcid.org/0000-0002-2475-9658.

${ }^{1}$ É. Durkheim, Le suicide. Étude de sociologie, Paris: Librairie Germer Baillière et Cie: Librairie Félix Alcan 1897. Nawet Émile Durkheim, jeden z najwybitniejszych socjologów świata, który dał podwaliny rozumieniu wsparcia społecznego w naukach społecznych, nie doczekał się jego integralnej koncepcji w naukach socjologicznych. Jako pierwszy wyraził on opinię, że relacje międzyludzkie mogą prowadzić do krytycznych sytuacji i wpływać niekorzystnie na zdrowie ludzkie oraz zachowania interpersonalne.

${ }^{2} \mathrm{H}$. SĘK, R. CIEŚLAK, Wsparcie spoteczne - sposoby definiowania, rodzaje i źródta wsparcia, wybrane koncepcje teoretyczne, w: Wsparcie spoteczne, stres i zdrowie, red. ciż, Warszawa: Wydawnictwo PWN 2011, s. 14. 
Pierwsze obejmuje formy wsparcia udzielanego przez najbliższy krąg rodziny, przyjaciół, sąsiadów, drugie lokuje się w przestrzeni pomocy instytucjonalnej (na poziomie państwa, instytucji samorządów, bezpieczeństwa społecznego, organizacji charytatywnych, non profit), ostatnie - profesjonalne jest domeną poradni psychologicznych, społecznych i rodzinnych. W tym kontekście wypada odwołać się do sieci społecznych więzi pomocy realizowanej w ramach wsparcia strukturalnego. Sieci te (naturalne grupy odniesienia, grupy formalne, instytucje, organizacje) pełnią rzeczywiste i możliwe funkcje pomocowe, ponieważ udzielają wsparcia swoim członkom, osobom, dla których sieć ta jest potencjalnie dostępna ${ }^{3}$.

Analizując sieć wsparcia w polityce społecznej, również w obszarze bezpieczeństwa społecznego, szczególnie w odniesieniu do zjawiska migracji trzeciej generacji, należy zwrócić uwagę na następujące podmioty wsparcia: państwo, samorząd terytorialny, szkołę, związki wyznaniowe (Kościół) oraz media. Stąd też głównym celem niniejszego artykułu jest ukazanie sieci wielorakiego wsparcia rodziny $\mathrm{w}$ rozłące migracyjnej w odniesieniu do polityki społecznej (bezpieczeństwa społecznego rodziny) na poziomie naukowym i praktycznym.

\section{WSPARCIE PAŃSTWA SPRZYJAJACE RODZINIE MIGRACYJNEJ}

Globalna polityka państwa wobec obywateli powinna odznaczać się dobrem społecznym aplikowanym na rzecz rodzin znajdujących w szczególnej sytuacji ze względu na wyzwania nowoczesności. Migracja poakcesyjna niewątpliwie należy do takich wyzwań. Polityka społeczna bowiem to działalność państwa wraz z innymi instytucjami pożytku publicznego. Podstawowym jej zadaniem jest optymalizacja warunków życia i pracy swoich obywateli, czyli poprawa położenia materialnego, asekuracja przed różnymi życiowymi zagrożeniami, a nade wszystko kompensowanie i wyrównywanie szans życiowych grup społeczeństwa, szczególnie socjalnie najsłabszych ${ }^{4}$, oraz „kształtowanie ogólnych warunków pracy i bytu ludności”,

${ }^{3}$ D. Gizicka, J. Gorbaniuk, M. SZYSZKa, Rodzina $w$ sytuacji roztaki migracyjnej, Lublin: Wydawnictwo KUL 2010, s. 40.

${ }^{4}$ K. PODOLSKI, W. TURNOWIECKI, Polityka społeczna, Gdańsk: Wydawnictwo Uniwersytetu Gdańskiego 2003, s. 7; J. AuleYTner, K. GŁĄBICKA, Polityka społeczna pomiędzy opiekuńczościa a pomocniczościa, Warszawa: Wyższa Szkoła Pedagogiczna Towarzystwa Wiedzy Powszechnej 2000, s. 16.

${ }_{5}^{5}$ Por. Polityka spoteczna, red. A. Kurzynowski, Warszawa: Wydawnictwo Szkoła Główna Hansdlowa 2002, s. 9. 
Migracja zarobkowa, chociaż przynosi wiele korzyści (szczególnie ekonomicznych), bywa jednak również dla jej uczestników źródłem trudności, dysfunkcji, a nawet patologii. Przyczyna tych problemów może znajdować się nie tylko w mikrostrukturze rodziny, ale też w makrostrukturze społeczeństwa. $Z$ tej też racji rodzinom migracyjnym należy się pomoc.

Rola państwa wobec tej kategorii rodzin powinna wyrażać się w konkretnych strategiach legislacyjnych oraz ekonomicznych. Trzeba zauważyć, że w ostatnim pięcioleciu brak pracy nie jest bezpośrednią przyczyną migracji ${ }^{6}$. Obniżenie poziomu bezrobocia do 3,0\% umożliwia podjęcie pracy nawet w konkurujących firmach. W zakresie działań podejmowanych przez państwo mieści się natomiast prowadzona obecnie polityka rodzinna, m.in. program Rodzina 500+, uwzględniająca nie tylko rodziny wielodzietne, ale ogół rodzin mieszkających na terytorium Polski. Te dobre inicjatywy i sprzyjające warunki bytowe przyczyniają się przynajmniej pośrednio do wzmożonej remigracji.

Korzystne wydaje się również prawo sprzyjające rodzinie w rozłące migracyjnej. Warto dodać, że migracja zarobkowa, szczególnie obydwojga rodziców, może skutkować wieloma zaniedbaniami w zakresie opieki nad dziećmi. Wprawdzie różnorodne akty prawne zapewniają dziecku prawo do opieki i ochrony, ale niestety nie zawsze są one stosowane. Wówczas dziecko traktowane jest jako osoba porzucona. Rodzice zaś nawet nie uświadamiają sobie możliwości popełnienia przestępstwa i ciążącej na nich odpowiedzialności karnej, rzadko bowiem pozostawienie dziecka bez prawnej opieki traktują jako porzucenie. Ten brak właściwej opieki zdrowotnej, materialnej, zaspokajania podstawowych potrzeb fizycznych i emocjonalnych dzieci to tylko jeden przykład braku stymulacji ich rozwoju?

Inną ważną formą pomocowych inicjatyw rządu jest koordynacja zabezpieczenia społecznego. Zabezpieczanie społeczne jawi się jako konieczny warunek ochrony obywatela w razie przypadków losowych, takich jak: choroba, wypadek, stan niepełnosprawności, a także ochrony ubezpieczonych i ich rodzin podejmujących zatrudnienie w granicach geograficznych Unii Europejskiej ${ }^{8}$. Zdaniem Zofii Kawczyńskiej-Butryn i Marzeny Kruk „w katalogu świadczeń objętych

\footnotetext{
${ }^{6}$ Oczywiście każda jednostka czy rodzina mają absolutne prawo do zmiany zamieszkania, pracy, również wybierając kraj emigracji. Czym innym jest jednak dobrowolna decyzja o wyjeździe, a czym innym swoisty przymus ekonomiczny, np. wynikający z zamknięcia zakładu pracy.

${ }^{7}$ E. MituŁA, Rodziny petne nie w petni - eurosieroctwo. Opieka nad dzieckiem a migracja zarobkowa rodziców, w: Rodzina we wspótczesności, red. A. Ładyżyński, Wrocław: Oficyna Wydawnicza Atut - Wrocławskie Wydawnictwo Oświatowe 2009, s. 168.

${ }^{8}$ K. PODOLSKI, W. TurNowIECKI, Polityka społeczna, s. 125. Wraz z akcesem Polski do struktur Unii Europejskiej w 2004 roku koordynacją został objęty również polski system zabezpieczenia.
} 
koordynacją znalazły się następujące świadczenia: w razie choroby i macierzyństwa, inwalidzkie, dla członków rodziny zmarłego żywiciela, z tytułu wypadków przy pracy lub choroby zawodowej, także zasiłki pogrzebowe, zasiłki dla bezrobotnych" .

Do kolejnych inicjatyw skierowanych do beneficjentów rozłąki migracyjnej trzeba zaliczyć szereg działań podejmowanych przez Ministerstwo Edukacji Narodowej. Należą do nich: telefon zaufania dla dzieci i młodzieży (współpraca MEN z Fundacją Dzieci Niczyje ${ }^{10}$ ), broszury o charakterze informacyjnym we współpracy z kuratoriami oświaty, kampanie informacyjne dotyczące postępowania $\mathrm{z}$ dzieckiem, którego rodzice wyjechali do pracy za granicę ${ }^{11}$. Ponadto Ministerstwo w celu zbadania skali migracji zarobkowej rodziców dzieci uczęszczających do szkół zlecało przeprowadzanie ankiet. Sondaże te dawały impuls do podejmowania aktywnych działań warunkujących wsparcie rodzin.

Jeszcze innym rodzajem wsparcia rodziny migracyjnej w państwie jest sąd administracyjny. Ideą jego działań jest odpowiedź na potrzebę ustanowienia opiekuna prawnego wobec dzieci pozostających w kraju. Niewątpliwie najwięcej problemów dotyczących nieobecności rodziców pojawia się w sytuacjach związanych z edukacją szkolną, ale również w przypadku choroby lub zachowań patologicznych, szczególnie zaś wobec konfliktu z prawem. Oczywiście część informacji szkolnych może być przekazana przez nauczyciela dziadkom lub najbliższej rodzinie. W przypadku jednak na przykład niedostatecznych ocen na koniec semestru tylko opiekun prawny może złożyć wniosek do rady pedagogicznej o przeprowadzenie dodatkowego egzaminu czy też prośbę o przyznanie dziecku indywidualnego nauczania. Nadto istotnym wydaje się zwrócenie uwagi na potrzeby opiekuna prawnego w sytuacji konieczności udzielenia dziecku pomocy: psychologicznej, pedagogicznej czy udzielanej przez inne poradnie specjalistyczne (np. logopedyczne, a także zajmujące się rozwiązywaniem problemów związanych np. z dysleksją, dysgrafią).

Pomoc ze strony sądu udzielana jest rodzinie w przypadku rzeczywistych potrzeb. Najczęściej wiąże się ona również z koniecznością ustanowienia kuratora sądowego. Nieobecność rodziców często prowadzi do różnych form demoralizacji. Organy państwa nie mogą pozostawać bierne wobec czynników prowadzących do desocjalizacji dziecka. Konwencja o prawach dziecka z 1989 roku ,,[...] traktuje dziecko jako podmiot prawa. Podmiotowość ta nie może być jednak

\footnotetext{
${ }^{9}$ Z. KAWCZYŃSKA-BUTRYM, M. KRUK, Wsparcie spoteczne dla rodzin migracyjnych $w$ Polsce, w: Rodzina wobec wyzwań wspótczesności, red. I. Taranowicz, S. Grotowska, Wrocław: Oficyna Wydawnicza Arboretum 2015, s. 213.

${ }^{10}$ Od 2016 roku fundacja ta działa pod nazwą: Fundacja Dajemy Dzieciom Siłę.

${ }^{11}$ L. PAWELEC, Instytucjonalne rozwiąywanie problemu dziecka $z$ syndromem eurosieroctwa, „Pedagogika Rodziny” 2015, nr 5/3, s. 97.
} 
postrzegana jako przyznanie pełnej zdolności do czynności prawnych. Stan świadomości, poziom rozwoju intelektualnego oraz nieukształtowany stan emocjonalny małoletnich przemawia za tym, by w celu ochrony ich dobra wyłączyć bądź w znacznym stopniu ograniczyć możliwość samodzielnego działania" ${ }^{\prime 2}$. W sytuacji braku kontaktu z rodzicem biologicznym i zarazem braku prawnego opiekuna sąd podejmuje decyzję o umieszczeniu dziecka w rodzinie zastępczej lub w ośrodku opiekuńczo-wychowawczym.

\section{SAMORZĄD TERYTORIALNY INSTYTUCJĄ WSPARCIA I BEZPIECZEŃSTWA DLA RODZINY W ROZŁĄCE MIGRACYJNEJ}

Samorząd terytorialny, a szczególnie gmina, jest najbliższym państwowym źródłem wsparcia rodziny migracyjnej. Według Czesława Strzeszewskiego charakteryzują go przynajmniej trzy cechy: wspólnotowość mieszkańców, troska o dobro ogólne oraz miejsce sprawowania władzy ${ }^{13}$. Wypada dodać jeszcze jedną cechę, a mianowicie troskę o rodzinę w sytuacjach trudnych wyzwań i socjalnych problemów. Niezależnie od ostatecznego ukształtowania struktur gospodarczych, organizacyjnych i prawodawczych państwa z racji członkowstwa kraju w Unii Europejskiej samorząd gminny zawsze egzystuje najbliżej swoich obywateli, tworząc „małe, lokalne ojczyzny”, do których będą należeć w granicach geograficznych miasta, wioski, parafie. Stąd też lokalne inicjatywy i pomysły rządzących, również wobec wyzwań rodzin migracyjnych, jawią się jako istotne symptomy wsparcia, a nawet prewencji.

Organizacja pomocy rodzinom migracyjnym przynależy zatem organom administracji samorządowej współpracującej z innymi organizacjami. Wśród nich można wskazać: społeczne, pozarządowe, Kościół katolicki oraz inne związki wyznaniowe. Gminy i powiaty tworzą na potrzeby obywateli specjalistyczne ośrodki pomocowe: regionalne ośrodki polityki społecznej, ośrodki pomocy społecznej, powiatowe centra pomocy rodzinie, placówki poradnictwa rodzinnego, placówki opiekuńczo-wychowawcze, ośrodki adopcyjno-opiekuńcze i wiele innych ośrodków pomocowych ${ }^{14}$.

Na pytanie, gdzie szukać pomocy, odpowiedź stanowi wskazanie miejskiego i gminnego ośrodka pomocy społecznej. Zwykle jest to pierwsze miejsce, do

\footnotetext{
${ }^{12}$ M. PomarańSKa-BieleckA, J. ZozUla, Wtadza rodzicielska i istota rodzicielstwa zastępczego, w: Rodzicielstwo zastępcze - komentarz do przepisów, red. O. Trocha, Warszawa: Stowarzyszenie Interwencji Prawnej 2010, s. 7.

${ }^{13}$ C. STRZESZEWSKI, Katolicka nauka społeczna, Lublin: Redakcja Wydawnictw KUL 1994, s. 528.

${ }^{14}$ J. KoRAL, Polityka spoteczna - wybrane zagadnienia, Warszawa: UKSW 2014, s. 29.
} 
którego zwracają się beneficjenci, szukając pomocy lokującej się w dwóch kategoriach świadczeń - pieniężnych i niepieniężnych. Można hipotetycznie założyć, że rodziny w sytuacji rozłąki bezpośrednio nie oczekują pomocy pieniężnej, ale pomocy $\mathrm{w}$ formie niepieniężnej, szczególnie profesjonalnej realizacji pracy socjalnej. Z badań przeprowadzonych w 2010 roku przez Dorotę Gizicką, Julię Gorbaniuk i Małgorzatę Szyszkę wynika, że z tego rodzaju pomocy korzystało wówczas $40 \%$ rodzin ${ }^{15}$. Do najczęstszych świadczeń pomocowych zaliczono: poradnictwo rodzinne i terapie rodzinne (pomoc psychologiczna i pedagogiczna) oraz pracę socjalną obejmującą zasiłki rodzinne i świadczenia socjalne.

Jeszcze inną formą wsparcia rodziny w rozłące migracyjnej jest Powiatowe Centrum Pomocy Rodzinie (PCPR), działające w strukturze samorządu terytorialnego. Celem tej instytucji jest diagnozowanie potrzeb oraz problemów rodzin znajdujących się w trudnej sytuacji. Realizując zadania powiatu, uczestniczy ona w rozwiązywaniu nie tylko problemów społecznych przy współpracy z ośrodkami pomocy społecznej, ale odpowiada też za integrację osób i rodzin zaliczanych do grup ryzyka. Szczególnym celem PCPR jest koordynowanie i wspieranie rodzin zastępczych oraz zapewnianie opieki dzieciom i młodzieży pozbawionym jej ze strony rodziców. Według Katarzyny Olczak-Baran instytucja ta ,pełni funkcję łącznika między gminnymi i miejskimi ośrodkami pomocy społecznej, regionalnymi ośrodkami polityki społecznej, urzędem wojewódzkim i organizacjami pozarządowymi $\mathrm{w}$ realizacji pozostających $\mathrm{w}$ gestii powiatu zadań opiekuńczo-socjalnych ukierunkowanych na pomoc dziecku i rodzinie"16.

Kolejnymi organizacjami wsparcia sieci społecznej są poradnie specjalistyczne: psychologiczne, pedagogiczne, realizujące programy zadaniowe i celowe, przede wszystkim przez udzielanie wsparcia środowiskowego oraz psychologicznego. Środowiskowe wsparcie daje osobom pozostałym w kraju większe poczucie bezpieczeństwa. Zwykle pierwszymi podmiotami wsparcia są sąsiedzi, bliscy znajomi, krewni, jednakże w sytuacji zaistnienia potrzeb wymagających specjalistycznej pomocy psychologicznej lub pedagogicznej cenna wydaje się aktywność profesjonalnie przygotowanych osób. Wsparcie psychologiczne nie tylko wpływa na pozytywne postrzeganie obiektywnych trudności związanych z wyjazdem najbliższej osoby, ale w sytuacji załamania pomaga zbudować sterowność relacji, poprawiając psychiczny stan osób, dla których wyjazd najbliższych doprowadził do trudności we właściwym funkcjonowaniu w społeczności lokalnej.

\footnotetext{
${ }^{15}$ D. GizICKA, J. GORBANIUK, M. SZYSZKA, Rodzina w sytuacji rozłaki migracyjnej, s. 143.

${ }^{16} \mathrm{~K}$. OlCZAK-BARAN, Instytucje wsparcia i pomocy rodzinie. Geneza, zadania i organizacja Powiatowego Centrum Pomocy Rodzinie, ,Wychowanie w Rodzinie” 2011, nr 4, s. 215.
} 
Ważnym aspektem wsparcia realizowanego wobec rodzin migracyjnych i emigracyjnych na poziomie samorządowym jest prowadzanie polityki prosenioralnej. $\mathrm{Z}$ racji starzejącego się społeczeństwa wzrasta zapotrzebowanie na pomoc seniorom i opiekę nad nimi ${ }^{17}$. Wydaje się, że w wyniku szeroko obserwowalnej mobilności jednostki, również w obszarze migracji zarobkowej oraz emigracji dorosłych dzieci z rodzinami, coraz częściej seniorzy (matki, ojcowie) doświadczają syndromu samotności. Niektórzy nawet drastycznie przerywają życie, dokonując czynów suicydalnych. W tym zakresie gminy realizują wiele programów UE, podejmując coraz więcej inicjatyw mających na celu wykorzystanie kapitału ludzkiego seniorów ${ }^{18}$ : intelektualnego, umiejętności, profesjonalizmu, doświadczenia ${ }^{19}$.

Prawie w każdej gminie prowadzone są zajęcia aktywizacji społecznej seniorów w zakresie aktywności fizycznej, intelektualnej, manualnej, kulturalnej. Powstaje coraz więcej organizacji, takich jak: uniwersytety trzeciego wieku, kluby seniora, kluby samopomocy, wolontariat, rady seniorów. Te ostatnie są często głosem doradczym dla gospodarzy gmin. Ważnymi miejscami są również ośrodki wsparcia dla seniorów: centra usług socjalnych dla osób starszych, domy dziennego pobytu, a także domy dla seniorów z zaburzeniami psychicznymi $^{20}$. Zgodnie z zapisem w ustawie o pomocy społecznej seniorzy z prywatnych domów i mieszkań, wykazujący deficyty w ramach samodzielności, otrzymują pomoc w formie usług opiekuńczych i specjalistycznych usług opiekuńczych. Art. 50 tej ustawy wskazuje, że tego typu usługi „mogą być przyznane również osobie, która wymaga pomocy innych osób, a rodzina, a także wspólnie niezamieszkujący małżonek, wstępni, zstępni nie mogą takiej pomocy zapewnić; [...] obejmują pomoc w zaspokajaniu codziennych potrzeb życiowych, opiekę higieniczną, zaleconą przez lekarza pielęgnację oraz, w miarę możliwości, zapewnienie kontaktów z otoczeniem,"21. Rolę taką pełnią opiekunowie społeczni oraz często asystenci rodziny.

${ }^{17}$ Zob. K. TRĘBSKI, Spolu kráčat' cestou života. Vybrané aspekty starostlivosti o seniorov a l'udí dlhodobo chorých [CD ROM], Trnava: Dobrá kniha 2019.

${ }^{18}$ I. POPIEL, Aspekty pojęciowe kapitatu ludzkiego i jego znaczenie, ,Studia Prawno-Ekonomiczne” 2015, nr 95, s. 301-315. Jednym z ekonomistów, który uważał, że człowieka można traktować jako formę kapitału, był Adam Smith. Jego najpopularniejsze dzieło w tej tematyce to Badania nad natura i przyczynami bogactwa narodów, Warszawa: Wydawnictwo PWN 1954. Kapitał ludzki nazwał on ,pożytecznymi umiejętnościami nabytymi w trakcie procesu kształcenia, które uznawał za osobisty majątek zarówno człowieka, jak i społeczeństwa”, s. 302.

${ }^{19} \mathrm{~W}$ niektórych gminach na stanowisko pełnomocnika do spraw polityki senioralnej powoływani są seniorzy środowiska lokalnego. Niewątpliwie to oni najlepiej znają potrzeby swoich rówieśników.

${ }^{20} \mathrm{~W} 2014$ roku ówczesny minister pracy i polityki społecznej ogłosił projekt programu dla seniorów pt. „Senior-WIGOR” na lata 2015-2020. Nazwę tego programu w ramach kontynuacji wsparcia seniorów zmieniono w 2016 roku na „Senior+”.

${ }^{21}$ Ustawa o pomocy społecznej z dnia 12 marca 2004 r. (Dz. U. 2004 r. Nr 64, poz. 593), art. 50 ust. 2-3. 
W katalogu wsparcia rodzin migracyjnych należy również uwzględnić umieszczenie osoby samotnej, często niewydolnej sprawnościowo i ruchowo, w domu pomocy społecznej. Seniorzy mogą także liczyć na pomoc w zakresie opieki paliatywnej, organizowaną w hospicjach stacjonarnych i domowych ${ }^{22}$, jednak tylko w niektórych miastach (np. Tarnów dotychczas nie ma hospicjum stacjonarnego). Niestety kwestia opieki poszpitalnej seniorów w zakresie stacjonarnej rehabilitacji czy przygotowanych miejsc rehabilitacyjnych ciągle jest niewystarczająca. Trzeba żywić nadzieję, że realizowany program „Senior+” docelowo będzie dotyczył nie tylko wsparcia finansowego i aktywizacji, ale również tak bardzo potrzebnej opieki w ostatnim stadium egzystencji człowieka (stadium dojrzewania do odejścia).

\section{ROLA SZKOŁY W UDZIELANIU WSPARCIA RODZINIE Z DOŚWIADCZENIEM MIGRACJI (EUROSIEROTY)}

W ramach polityki społecznej na poziomie samorządu gminnego uwzględnić wypada realizację zadań przez szkoły. Stanowią one przestrzeń dla spójnych działań naukowych i wychowawczych, a także są pierwszym miejscem kontaktu z uczniami i ich rodzicami. Tworzą relacje społeczne oraz kształtują kanon uniwersalnych wartości ludzkich. W szkole dostrzec można swoisty aksjologiczny świat, w którym holistyczna harmonia panująca w rodzinie dziecka stanowi ważną wartość. Dzięki temu środowisko szkolne łatwo zauważa problemy wychowawcze rodzące się $\mathrm{w}$ rodzinach $\mathrm{z}$ doświadczeniem migracji.

Z pewnością pierwszą osobą do kontaktu w szkole jest wychowawca danej klasy, potem dyrektor i w dalszej kolejności inni pedagodzy. Istnieje duże prawdopodobieństwo, że dzieci czy dorastająca młodzież, w związku z rozłąką migracyjną, doświadczą poczucia zagubienia. Ma na to wpływ przede wszystkim fakt, że nieobecność matki lub ojca nakłada na drugiego rodzica wiele dodatkowych obowiązków i ról rodzicielskich. Zwykle jest on zobligowany do zweryfikowania pełnionych dotychczas ról oraz podjęcia nowych. Tego typu sytuacje warunkują egzystencję nie tylko w przypadku migracji wahadłowej (całorocznej), ale również sezonowej.

Chociaż szkoła często diagnozuje skalę zjawiska migracji, to jednak nie zawsze jest w stanie trafnie ocenić sytuację w rodzinie. Tymczasem rozłąka rodzica z dzieckiem nie tylko przyczynia się do pojawienia się wielu zagrożeń,

\footnotetext{
${ }^{22} \mathrm{~K}$. TRĘBSKI, Niektoré základné pojmy v geriatrickej a dlhodobej starostlivosti, w: Dozrievanie v láske, red. M. Šmidová, Trnava: Dobrá kniha 2014, s. 29-49.
} 
ale też wpływa na proces wychowania i socjalizacji dziecka, które często w takiej sytuacji rozwija się przede wszystkim w grupie rówieśniczej ${ }^{23}$. W raporcie przygotowanym przez Kuratorium Oświaty w Tarnowie w 2012 roku zanotowano u dzieci migrantów: pogorszenie wyników w nauce, pogorszenie frekwencji, trudności w zakresie przestrzegania norm porządkowych, dyscyplinarnych, zaburzenia emocjonalne, depresje, agresje, brak kontroli emocjonalnej.

Szkoła edukuje i wychowuje, zawsze pozostając instytucją lokalną, przyjazną wobec dzieci i ich rodziców, również w sytuacji różnych zaburzeń i dysfunkcji. Stąd też rodzice w rozłące migracyjnej otrzymują pomoc w zakresie współpracy z dyrektorem, wychowawcą, a w sytuacjach trudnych - z pedagogiem i psychologiem szkolnym ${ }^{24}$. Wsparcie rodziny przez szkołę realizowane jest przynajmniej na kilku poziomach: nauczania, wychowania, opieki i profilaktyki. Wymagania edukacyjne dostosowane są do możliwości ucznia, zapewniane są dodatkowe zajęcia, pomoc w odrabianiu lekcji, prowadzone są zajęcia wyrównawcze, korekcyjne, kompensacyjne, socjoterapeutyczne oraz indywidualne spotkania z nauczycielem. Dzieci z rodzin migracyjnych korzystają z dodatkowych zajęć związanych szczególnie z ich zainteresowaniami i zdolnościami, a także z oferty zajęć pozalekcyjnych prowadzonych we współpracy z opiekunami i specjalistami. W ramach opieki rodzice korzystają z konsultacji na temat koniecznej normalizacji prawnej w zakresie ustanowienia opiekuna prawnego, szczególnie w przypadku wyjazdu obojga rodziców. Wielu uczniów korzysta ze świetlicy szkolnej, a także z codziennych posiłków. Z kolei w ramach działań profilaktycznych rodzice otrzymują pomoc na wypadek ryzykownych zachowań dzieci (uzależnienia, agresja, konflikty), korzystają też z programów wychowawczo-prewencyjnych. Każdy nauczyciel udziela ponadto $\mathrm{w}$ zakresie posiadanych kompetencji pomocy adekwatnej do poziomu trudności i potrzeb. Pomoc ta świadczona jest także w sytuacji, gdy prawo opieki nad dzieckiem sprawują dziadkowie ${ }^{25}$.

\footnotetext{
${ }^{23} \mathrm{Z}$ analiz Systemu Informacji Oświatowej (SIO) wynika, że ,,[...] we wrześniu 2016 roku liczba uczniów z rodzin rozłączonych przestrzennie kształtuje się na poziomie 5,89\%. Wskaźnik uzyskany na podstawie diagnozy prowadzonej wśród uczniów to 19,9\%. Najmniejszy odsetek uczniów deklarujących wyjazd rodziców do pracy za granicę odnotowano w województwach wielkopolskim $(16,2 \%)$ i podlaskim $(16,9 \%)$. Najwyższy odsetek dotyczył zachodniopomorskiego $(28,4 \%)$, pomorskiego $(22,5 \%)$, małopolskiego $(22,9 \%)$ i lubuskiego $(23,5 \%)$. W skali całego kraju liczba uczniów z rodzin migracyjnych może sięgać 640 tysięcy. Spośród badanych dzieci i młodzieży 7,2\% wychowuje się w rodzinach, w których obydwoje rodzice zdecydowali się na podjęcie zatrudnienia poza Polską". A. DĄBRowsKa, E.M. SzumILAS, Uczniowie z rodzin migracyjnych w szkole, Warszawa: Ośrodek Rozwoju Edukacji 2017, s. 12.

${ }^{24}$ Należy nadmienić, że niestety w polskich uwarunkowaniach nie we wszystkich szkołach jest zatrudniony pedagog czy psycholog. Wówczas szkoła współpracuje z miejskimi i gminnymi ośrodkami pomocy społecznej.

${ }^{25}$ A. DąBrowska, E.M. Szumilas, Uczniowie z rodzin migracyjnych w szkole, s. 76.
} 
W kluczu omawianego zagadnienia istotnym obszarem jest zwrócenie uwagi na zjawisko eurosieroctwa. Zdaniem Stanisława Kozaka „eurosierota to dziecko, które wychowuje się bez co najmniej jednego rodzica, który wyjechał za granicę w celach zarobkowych"26. Oczywiście wskazane powyżej formy pomocy oferowanej przez szkołę są adekwatne również w obliczu eurosieroctwa. Na ogół wsparcie udzielane jest na zasadach określonych w ustawie o systemie oświaty i obejmuje działania podejmowane „w sprawie udzielania i organizacji pomocy psychologiczno-pedagogicznej w szkołach i placówkach, w sprawie szczegółowych zasad działania publicznych poradni psychologiczno-pedagogicznych, w tym publicznych poradni specjalistycznych, w sprawie orzeczeń i opinii wydawanych przez zespoły orzekające, działające w publicznych poradniach psychologiczno-pedagogicznych" ${ }^{\text {27 }}$.

Rodziny migracyjne dotknięte eurosieroctwem - beneficjenci sieci wielorakiego wsparcia - otrzymują to, co najważniejsze, tj. zainteresowanie uczniem, jego sytuacją bytową w szkole, również sytuacją bytową w domu, budowanie w dziecku poczucia wartości. Świadczone są na ich rzecz również inne formy wsparcia, mieszczące się w katalogu pomocy szkolnej, na ogół przy współpracy $\mathrm{z}$ innymi organizacjami i placówkami pomocowymi ${ }^{28}$. Przywołany raport Kuratorium Oświaty w Tarnowie uświadamia ważność pomocy rodzinie z doświadczeniem migracji. Jego autorzy stwierdzają, że integralnym wsparciem jest upowszechnianie wśród zainteresowanych wiedzy o prawnych i psychoedukacyjnych następstwach wyjazdów w celu podjęcia pracy w kraju docelowym. $\mathrm{Z}$ informacji tych rodzice korzystają podczas konferencji i zebrań z wychowawcami ${ }^{29}$.

\section{ZWIĄZKI WYZNANIOWE (KOŚCIÓŁ) A WSPARCIE RODZINY MIGRACYJNEJ}

Jedną z cech, którą odznaczają się Kościół katolicki i związki wyznaniowe, jest wspólnotowość. Parafia łączy, kształtuje relacje i umacnia więzi społeczne. W strukturze lokalnej społeczności stanowi najczęstsze miejsce spotkań członków

\footnotetext{
${ }^{26}$ S. KozaK, Patologia eurosieroctwa w Polsce: skutki migracji zarobkowej dla dzieci i ich rodzin, Warszawa: Wydawnictwo Difin 2010, s. 113.

${ }^{27}$ E. OsĘKOwSKA, Funkcjonowanie dzieci migrantów wahadtowych - analiza problemu, „Rocznik Komisji Nauk Pedagogicznych” 2017, nr 70, s. 184.

${ }^{28}$ B. BANASIAK, A. RogalSKA-MARASIŃSKA, Uczeń wobec wyzwań wspótczesności, Łódź: Wydawnictwo Uniwersytetu Łódzkiego 2010, s. 215.

${ }^{29}$ J. MŁYŃSKI, W. SZEWCZYK, Rodzina wobec dylematów migracji zarobkowej, Warszawa: Instytut Papieża Jana Pawła II 2012, s. 155.
} 
wspólnoty parafialnej. $Z$ tego też powodu rodziny migracyjne uczestniczą w różnych formach pomocy oferowanej przez Kościół lub związki wyznaniowe.

Oczywiście pomoc w rozłące migracyjnej nie powinna być skierowana jedynie do osób o określonym stopniu praktykowania wiary ani też wyłącznie przez takie oczekiwana. Wprawdzie legitymizacja członków Kościoła i ich związek $\mathrm{z}$ nim są ważne, jednak wsparcie $\mathrm{w}$ omawianym zakresie oferowane jest wszystkim potrzebującym zamieszkującym obszar danej parafii, również niepraktykującym, a nawet niewierzącym. Wydaje się, że właśnie w tym aspekcie można upatrywać podmiotowość Kościoła względem jednostek i rodzin znajdujących się w trudnej sytuacji egzystencjalnej ${ }^{30}$.

Rodzina migracyjna najczęściej korzysta z pomocy pastoralnej, duszpasterskiej na poziomie wsparcia duchowego, rzeczowego oraz profesjonalnej pomocy w sytuacji kryzysów małżeńskich. Ten pastoralny wymiar w ramach spotkań umacnia duchowo, a na płaszczyźnie psychicznej budzi świadomość ciągłego myślenia o osobie, która wyjechała. Umacnia także religijnie. W kościołach istnieją przykłady grup tworzonych przez żony, które w ramach comiesięcznych spotkań duchowo wspierają mężów pracujących w innym kraju (zwykle przyjeżdżających na weekendy, raz w miesiącu lub przynajmniej co trzy miesiące). Ta stała opieka duchowa nie tylko pomaga łączyć małżonków i ich dzieci, ale też buduje więzi z parafią, dając poczucie bezpieczeństwa psychicznego rodziny migracyjnej.

Troska Kościoła o rodziny niepełne (migracyjne) jest bardzo ważna chociażby $\mathrm{z}$ tej racji, że tego rodzaju rodziny zaliczane są w pewnym sensie do dysfunkcyjnych. $Z$ powodu nieobecności rodzica $w$ świadomości dziecka rodzą się dysfunkcje w procesie wychowania, dojrzewania, pełnienia ról społecznych, rodzinnych, również w zakresie odmienności płci. Kościól, świadomy możliwych problemów wychowawczych, w ramach aktywności pastoralnych diagnozuje skalę migracji w danej parafii i podejmuje działania pomocowe, organizując na przykład kolonie, półkolonie, letnie i zimowe obozy sportowe. W okresach świątecznych otacza troską duchową powracających na ten czas do domów oraz tych, którzy z różnych powodów nie mogą uczestniczyć w rodzinnym świętowaniu. Inicjatywy te są przedmiotem troski Kościoła powszechnego i partykularnego oraz innych związków wyznaniowych ${ }^{31}$.

Migracja zarobkowa niesie ze sobą również wiele konsekwencji w obszarze relacji małżeńskich, zaburza więzi małżeńskie, wychowawcze, może doprowadzić

\footnotetext{
${ }^{30}$ D. GizickA, J. GorbaniuK, M. SZYSZKa, Rodzina w sytuacji roztaki migracyjnej, s. 45-46.

${ }^{31}$ Jan Paweł II jako pierwszy spośród papieży wygłaszał orędzia na Światowe Dni Migranta. Zob. Jan PaweŁ II, Orędzia na Światowy Dzień Migranta i Uchodźcy (1985-2005), oprac. W. Necel, Poznań: Wydawnictwo Towarzystwa Chrystusowego Hlondianum 2009.
} 
do degradacji moralnej, często do dramatu rodziny (na przykład rozwodu). Jest zazwyczaj przyczyną wielu kryzysów. W takich okolicznościach rodziny w rozłące migracyjnej mogą otrzymać pomoc w postaci terapii małżeńskich. Specjalistyczne poradnie rodzinne dysponują profesjonalnie przygotowanymi osobami, duchownymi i świeckimi, udzielającymi porad i ratującymi małżeństwa $\mathrm{w}$ konflikcie. Ten rodzaj counsellingu ${ }^{32}$ jawi się jako istotna metoda wsparcia rodzin migracyjnych ${ }^{33}$. W latach 2011-2017 z pomocy świadczonej przez specjalistów (doradców) w poradni specjalistycznej ARKA w Tarnowie i jej oddziałach skorzystało prawie 19 tys. osób. Znaczna liczba przypadków dotyczyła problemów związanych z migracją ekonomiczną ${ }^{34}$.

Jeszcze inną formą wsparcia rodzin migracyjnych jest oferta Kościoła w zakresie pomocy rzeczowej. Trzeba przyznać, że wielu wyjeżdżającym nie udało się zrealizować swoich zamierzeń. Nie tylko zagubili się religijnie, ale także utracili tożsamość rodzinną i społeczną. $Z$ tej też racji Caritas diecezjalna organizuje pomoc rzeczową - finansową i opiekuńczą. Dobry przykład działań wspierających stanowią również lokalne inicjatywy parafii (Kościołów) i związków wyznaniowych.

\section{MEDIA - POŚREDNIE WSPARCIE MIGRANTÓW NA ODLEGŁOŚĆ}

Niewątpliwie w panoramie pomocowej skierowanej do beneficjentów migracyjnych, przynajmniej pośrednio, są też media społecznościowe. Z pewnością nikt ani nic nie zastąpi fizycznej obecności osoby. Niemniej jednak w obliczu migracji zarobkowej ten rodzaj wsparcia owocuje wieloma pozytywnymi rezultatami. W zakres pomocowy wpisują się mobilne aplikacje, strony internetowe, e-maile, portale społecznościowe, smartfony ${ }^{35}$. Trzeba przyznać, że komunikacja interpersonalna, szczególnie małżeńska (partnerska) i rodzinna, dokonuje się na

\footnotetext{
${ }^{32}$ Zagadnienie poradnictwa (counsellingu) jest szeroko omawiane przez Krzysztofa Trębskiego. Zob. K. TręBSKI, Counselling ako pomáhajúci vzt’ah a pastoračné sprevádzanie, Trnava: Dobrá kniha 2016.

${ }^{33}$ W Tarnowie od czterdziestu lat działa Poradnia Specjalistyczna i Telefon Zaufania „Arka”. Stowarzyszenie to zostało założone w 1982 roku przez W. Szewczyka, a w 1990 roku powstał telefon zaufania. Po kilku latach funkcjonowania „Arki” w Tarnowie założyciel postanowił poszerzyć jej działalność o nowe poradnie w Bochni, Dębicy, Mielcu i Nowym Sączu.

${ }^{34}$ W. SZEwCZYK, J. MŁYŃSKi, E. ZIĘBA, Rozmowy, które lecza, Tarnów: Poligrafia Redemptorystów 2017, s. 51.

${ }^{35}$ Dobrze się stało, że unijne prawodawstwo w 2017 roku wprowadziło zmiany dotyczące roamingu. Wynika z nich, że korzystając $\mathrm{z}$ telefonu komórkowego podczas podróży do krajów unijnych, jak również w przypadku częstych powrotów z pracy za granicą, osoba nie musi ponosić dodatkowych kosztów.
} 
szerszym tle relacji między członkami rodziny. Relacje bowiem to zespół interakcji (działań, komunikacji werbalnej i niewerbalnej), określający to, co dzieje się między adresatami rozmowy w danym czasie. Są one wpisane w proces umacniania więzi małżeńskich i rodzicielskich ${ }^{36}$. Migranci, ze względu na doświadczanie odmiennej rzeczywistości kulturowej i społecznej, dzięki portalom podtrzymują relacje z bliskimi. Według Iwony Leonowicz-Bukały „,...] należy zauważyć, że istnienie aplikacji typu Skype czy portali, takich jak: Facebook, MySpace i innych o zasięgu światowym, a także polskich - jak nasza-klasa, uniezależnia internautę od miejsca zamieszkania czy pochodzenia. Zatem korzystanie z nich przez migrantów wydaje się szczególnie atrakcyjne. Platformy te ułatwiają znacznie codzienne kontakty z rodziną i znajomymi w Polsce, w istotny sposób zacierają barierę dzielącej użytkowników przestrzeni. Korzystają oni z nich przecież niemal codziennie: zamieszczają zdjęcia, przekazują sobie wiadomości w sposób synchroniczny i asynchroniczny" ${ }^{37}$.

Zastosowanie portali społecznościowych wydaje się cenne nie tylko w aspekcie rozmów między małżonkami, ale również w odniesieniu do roli wychowawczej wobec dzieci. Możliwość zobaczenia się face to face daje poczucie bliskości, także na płaszczyźnie emocjonalnej. Stwarza bowiem przestrzeń na wyrażanie uczuć: tęsknoty, smutku, zmartwienia. Pozwala na wysłuchanie dziecka, wspólne odrabianie zadań domowych, czytanie bajek, zabawę itd. Omawiając strategie wychowawcze rodziców na emigracji na podstawie przeprowadzonych badań, Agnieszka Pawlak przytacza m.in. następującą wypowiedź ojca na emigracji: „Rozmawialiśmy przez telefon, Skype’a, dzieci wysyłały mi też wiadomości e-mailem ze swoimi zdjęciami albo rysunkami dla mnie. Staraliśmy się rozmawiać jak najczęściej, ale wiadomo było to trudne, bo ja miałem czas wieczorem, kiedy one już spały albo rano, gdy córka była w szkole. Najczęściej rozmawialiśmy w weekendy, wtedy żona zawsze dbała o to. Rozmawialiśmy o tym, jak nam minął tydzień, córka opowiadała, jak było w szkole i jak mijają jej przygotowania do Komunii, a mały chwalił się tym, co już potrafi powiedzieć" ${ }^{38}$.

\footnotetext{
${ }^{36}$ B. HARWAS-NAPIERAŁA, Komunikacja $w$ rodzinie ujmowanej jako system $w$ relacji rodzice - dzieci, „Roczniki Socjologii Rodziny” 2006, nr 17, s. 221.

${ }^{37}$ I. LeONOWiCZ-BuKAŁA, E-migracja 2.0. Internet jako przedmiot badań migracyjnych, „Komunikacja Społeczna. Kwartalnik Internetowy” 2013, nr 3 (7), s. 66-67.

${ }^{38}$ A. PAWLAK, „Poczytaj mi mamo przez Skype'a”. Negocjowanie zakresu i modyfikowanie ról rodzinnych $w$ rodzinach $z$ doświadczeniem emigracji zarobkowej, „Pogranicze. Studia Społeczne” 24 (2014), nr 49, s. 67.
} 


\section{ZAKOŃCZENIE}

Migracja poakcesyjna na trwałe wpisała się w przestrzeń funkcjonowania rodzin społeczeństwa polskiego oraz w ich poczucie bezpieczeństwa. Geneza decyzji migracyjnych jest wieloraka i trudno obiektywnie ocenić ich zasadność. Powodują one rozłąkę migracyjną rodzin przynoszącą wiele pozytywnych skutków. Nierzadko jednak w dyskursie naukowym zwraca się również uwagę na te jej konsekwencje, które dezorganizują ludzką egzystencję. Dotyka ona bowiem środowiska małżeńskiego, rodzinnego i społecznego.

Z tej też przyczyny sieć wielorakiego wsparcia, którego beneficjentami są rodziny migrantów, jest nieoceniona. Trzeba przyznać, że w ramach tego wsparcia wskazane podmioty: państwo, samorząd terytorialny, związki wyznaniowe (Kościół) oraz media pełnią rolę pomocniczą. Wsparcie to przecież nie rozwiąże wszystkich problemów związanych z doświadczeniem, a nawet syndromem pustego miejsca w rodzinie migracyjnej. Ryzyko migracji i jej koszty są duże, ale osoby, które na nią się decydują, wypierają ze swojej świadomości jej negatywne strony, koncentrując się na szansach, które daje nowoczesna mobilność.

Migracja jest niewątpliwie „lustrem” wielu przemian wpływających na życie rodziny i dzieci. Nigdy jednak realizacja polityki społecznej nie może być obca w zakresie oferowanego wsparcia. W orbicie tego wsparcia w strukturze społecznej nadrzędnym podmiotem pozostaje rodzina, również ta $\mathrm{z}$ doświadczeniem migracji. Wydaje się, że to oferowane wsparcie, szczególnie na poziomie lokalnym, przyjmuje z punktu widzenia naukowego i weryfikowalnego status obiectum. Jednak ,z uwagi na nieustanne zmiany w tym zakresie i zróżnicowane skutki dla rodziny, jednostki i społeczeństwa warto monitorować i eksplorować to zjawisko"39 oraz ciągle diagnozować sytuację rodzin migracyjnych.

\section{BIBLIOGRAFIA}

Auleytner J., GŁĄBicKa K., Polityka społeczna pomiędzy opiekuńczością a pomocniczością, Warszawa: Wyższa Szkoła Pedagogiczna Towarzystwa Wiedzy Powszechnej 2000.

BANASIAK B., Rogalska-MarasińSKa A., Uczeń wobec wyzwań współczesności, Łódź: Wydawnictwo Uniwersytetu Łódzkiego 2010.

BeCKer-PestKa D., Rodzina w obliczu migracji zarobkowej, „Colloquium Wydziału Nauk Humanistycznych i Społecznych. Kwartalnik” 2012, nr 1, s. 9-26.

\footnotetext{
${ }^{39}$ D. BECKER-PESTKA, Rodzina w obliczu migracji zarobkowej, „Colloquium Wydziału Nauk Humanistycznych i Społecznych. Kwartalnik” 2012, nr 1, s. 23.
} 
DĄBRowska A., SzUMILAS E.M., Uczniowie z rodzin migracyjnych w szkole, Warszawa: Ośrodek Rozwoju Edukacji 2017.

Durkheim É., Le suicide. Étude de sociologie, Paris: Librairie Germer Baillière et Cie: Librairie Félix Alcan 1897.

Gizicka D., Gorbaniuk J., Szyszka M., Rodzina w sytuacji rozłąki migracyjnej, Lublin: Wydawnictwo KUL 2010.

HARWAS-NAPIERAŁA B., Komunikacja w rodzinie ujmowanej jako system w relacji rodzice - dzieci, „Roczniki Socjologii Rodziny” 2006, nr 17, s. 221-233.

JAN PAweŁ II, Orędzia na Światowy Dzień Migranta i Uchodźcy (1985-2005), oprac. W. Necel, Poznań: Wydawnictwo Towarzystwa Chrystusowego Hlondianum 2009.

KAWCZYŃSKA-BUTRYM Z., KRUK M., Wsparcie społeczne dla rodzin migracyjnych w Polsce, w: Rodzina wobec wyzwań współczesności, red. I. Taranowicz, S. Grotowska, Wrocław: Oficyna Wydawnicza Arboretum 2015, s. 205-217.

KoRAl J., Polityka społeczna - wybrane zagadnienia, Warszawa: UKSW 2014.

Kozak S., Patologia eurosieroctwa w Polsce: skutki migracji zarobkowej dla dzieci i ich rodzin, Warszawa: Wydawnictwo Difin 2010.

LEONOWICZ-BuKAŁA I., E-migracja 2.0. Internet jako przedmiot badań migracyjnych, „Komunikacja Społeczna. Kwartalnik Internetowy" 2013, nr 3 (7), s. 57-71, pobrano z: www.komunikacja spoleczna.edu.pl [dostęp: 23.07.2019].

MituŁA E., Rodziny pełne nie w pełni - eurosieroctwo. Opieka nad dzieckiem a migracja zarobkowa rodziców, w: Rodzina we współczesności, red. A. Ładyżyński, Wrocław: Oficyna Wydawnicza Atut - Wrocławskie Wydawnictwo Oświatowe 2009.

MŁYŃSKi J., SZEWCZYK W., Rodzina wobec dylematów migracji zarobkowej, Warszawa: Instytut Papieża Jana Pawła II 2012.

OlCZAK-BARAN K., Instytucje wsparcia i pomocy rodzinie. Geneza, zadania i organizacja Powiatowego Centrum Pomocy Rodzinie, ,Wychowanie w Rodzinie” 2011, nr 4, s. 209-228.

OsĘKOwSKA E., Funkcjonowanie dzieci migrantów wahadłowych - analiza problemu, „Rocznik Komisji Nauk Pedagogicznych" 2017, nr 70, s. 175-189.

PAWELEC L., Instytucjonalne rozwiązywanie problemu dziecka z syndromem eurosieroctwa, „Pedagogika Rodziny” 2015, nr 5/3, s. 93-104.

PAWLAK A., „Poczytaj mi mamo przez Skype'a”. Negocjowanie zakresu i modyfikowanie ról rodzinnych w rodzinach z doświadczeniem emigracji zarobkowej, „Pogranicze. Studia Społeczne” 24 (2014), nr 49, s. 49-72.

Podolski K., TuRnowiecki W., Polityka społeczna, Gdańsk: Wydawnictwo Uniwersytetu Gdańskiego 2003.

Polityka społeczna, red. A. Kurzynowski, Warszawa: Wydawnictwo Szkoła Główna Handlowa 2002.

POMARAŃSKA-BiElECKA M., ZozUla J., Władza rodzicielska i istota rodzicielstwa zastępczego, w: Rodzicielstwo zastępcze - komentarz do przepisów, red. O. Trocha, Warszawa: Stowarzyszenie Interwencji Prawnej 2010, s. 8-13.

POPIEl I., Aspekty pojęciowe kapitału ludzkiego i jego znaczenie, „Studia Prawno-Ekonomiczne” 2015, nr 95, s. 301-315.

SĘK H., CIEŚLAK R., Wsparcie społeczne - sposoby definiowania, rodzaje i źródła wsparcia, wybrane koncepcje teoretyczne, w: Wsparcie społeczne, stres i zdrowie, red. ciż, Warszawa: Wydawnictwo PWN 2011. 
SMITH A., Badania nad naturą i przyczynami bogactwa narodów, Warszawa: Wydawnictwo PWN 1954.

StRZESZEwsKi C., Katolicka nauka społeczna, Lublin: Redakcja Wydawnictw KUL 1994.

SZEWCZYK W., MŁYŃSKi J., ZIĘBA E., Rozmowy, które leczą, Tarnów: Poligrafia Redemptorystów 2017.

TrĘBSKI K., Counselling ako pomáhajúci vzt’ah a pastoračné sprevádzanie, Trnava: Dobrá kniha 2016.

TRĘBSKI K., Niektoré základné pojmy v geriatrickej a dlhodobej starostlivosti, w: Dozrievanie v láske, red. M. Šmidová, Trnava: Dobrá kniha 2014, s. 29-49.

TRĘBSKI K., Spolu kráčat' cestou života. Vybrané aspekty starostlivosti o seniorov a l'udí dlhodobo chorých [CD ROM], Trnava: Dobrá kniha 2019.

Ustawa o pomocy społecznej z dnia 12 marca 2004 r. (Dz. U. 2004 r. Nr 64, poz. 593), art. 50 ust. 2-3.

\section{RODZINA MIGRACYJNA \\ BENEFICJENTEM SIECI WSPARCIA W POLSCE}

\section{Streszczenie}

W artykule podjęto zagadnienie sieci wielorakiego wsparcia bezpieczeństwa społecznego rodziny migracyjnej w Polsce. Opisano podmioty, od których rodzina w rozłące, w różnych sytuacjach życiowych, otrzymuje pomoc. Rodzaj tej pomocy dostosowany jest do jej adresatów: dzieci, młodzieży, rodziny i społeczności lokalnej. Głównym celem niniejszego artykułu jest ukazanie sieci wielorakiego wsparcia udzielanego rodzinie w rozłące migracyjnej w ramach polityki społecznej, na poziomach - naukowym i praktycznym. W katalogu sieci wielorakiego wsparcia wyróżniono: państwo, samorząd terytorialny (dzieci, rodzina, seniorzy, szkoła), związki wyznaniowe (Kościół) oraz media.

Słowa kluczowe: rodzina; wsparcie; bezpieczeństwo społeczne; samorząd terytorialny; szkoła; media.

\section{A MIGRANT FAMILY AS A BENEFICIARY OF THE SUPPORT AND SOCIAL SECURITY NETWORK IN POLAND}

\section{Summary}

The article addresses the issue of multiple networks of support for the migration family in Poland. As part of its support, it describes entities from which the family will disconnect in various life situations. The type of this assistance is adapted to many areas: children, youth, family and local community. The main purpose of this article is to show the network of multiple family support in migration separation in social policy at the scientific and practical level. The catalog of multiple support networks includes: the state, local government (children, family, seniors, school), religious associations (Church) and the media.

Keywords: family; support; social security; local government; school; media. 